\title{
Improving the functioning of children, age 3-6 years, with central nervous system damage
}

\author{
Paulina Bartnik. ${ }^{1}{ }_{\text {ABCDEF}}$, Anna Haraszczuk-Dybowska. ${ }_{\text {ABCDEF}}$, Aneta Szerafin-Wrona. ${ }_{\text {ABCDEF}}$, \\ Krzysztof Metera ${ }^{2}$ ABCDEF \\ ${ }^{1}$ Special Preschool no 11 in Lublin, Poland \\ ${ }^{2}$ Faculty of Health Sciences, Vincent Pol University in Lublin, Poland
}

\begin{abstract}
Based on knowledge gained throughout years of working with children with cerebral palsy, teachers and specialists of the Special Preschool No. 11 in Lublin have developed their own functionality improving system for those disabled children. The main objectives of the system are to prepare children for independent life in society, development of physical activity, mastering everyday activities and opportunities to communicate. These assumptions are realized in the classroom in small groups of children.

Improving a group of children of the same age and similar rates of learning facilitates the repetition of acquired skills in various everyday situations.

Data on the development of children are collected and recorded in special sheets prepared by therapists. Parents of the child are asked to complete the sheet. Information taken from the observaation sheet form the basis to create a functional diagnosis for every child.

The rating scale GMFM (Motor Function Measure Gross) is an important complement to the assessment of the child's development. Educators, psychologists, speech therapists and a physical therapists make a functional diagnosis for each child, which forms the basis for the preparation of educational and therapeutic programme (Ipet.). The educational content of the programme is constructed in a "spiral pattern” with a view to broadening and deepening knowledge.

Cooperation of the therapeutic team with parents of disabled children is an essential condition for achieving progress in the child's development.
\end{abstract}

Key words: children, nervous system damage, functional improvement

\section{Introduction}

Objective of the project - Justification for the efficiency in functional improvement made by children aged 3 - 6 years with nervous system damage.

Main assumptions of functional improvement system followed in Special Kindergarten No. 11 in Lublin

Substantive consultation: M.D. Krzysztof Metera, prof. WSSP - Proxy Rector for Research Vincent Pol University (VPU) in Lublin

Special Kindergarten No 11 in Lublin is the only public institution around lubelskie province that is taking care of children with different disabilities. Basing on knowledge, taken from many years working with children with celebral palsy, teachers and specialist found the way to make their own functionality improving system for children with nervous system damage. The main assumption of the system is to prepare a child with disability for an independent life in the society, on the level that it is possible. To make this happen some important circumstances must be created so that education tasks can be introduced, with influence on:

- Neuromotorical function - learning how to move, to change place,
- Self -service function - learning how to do activities of daily living,

- Communication function -learning to speak, to communicate,

- Intelectual function - learning directional abilities.

All of the children attending the kindergarten, no matter what disabilities they suffer from, according to educational law, are implementing educational program based on core curriculum for pre-school education (Regulation of the Minister of National Education of 27 August 2012 on the core curriculum and general education in particular types of schools). As for children attending a special pre-school the only difference is the range of content and choice of accurate working methods. In Special Kindergarten no 11 in Lublin - according to children with celebral palsy, educational work was based on methods popular in special education - Maria Grzegorzewska work centres method, Maria Montessorii method, Weronika Sherborne method, M. \& Ch. Knill method, directed learning method. Working every day with those methods or some elements of those assured teachers that disa- 
bled child is the totality in all physical, emotional and intellectual aspects. Both, education and therapy of the child must be done in multi-dimensional way, it requires integrate approach, with the special input on improving independence in all spheres of life. Many working methods, used while working with physically disabled child, are based mainly on individual approach, while in kindergarten teachers work with groups of children mostly. Working with group of children, in the same age and similar learning speed, it is easy to repeat acquired skills in different situations of everyday life, during playing, it motivates, learn how to function in environment different than family. It is very important to impact on the child in the same way, as teachers do in the pre-school everywhere - at home, in associations, in institutionss -where child attend as well. Cooperating with child's family includes constant communication in order to determinate the direction and range of interactions, exchange information about child development course, how it improves, taking chances, and about its problems, difficulties and failures as well [1], [4].

Functional improving system in Special Pre-school no 11 in Lublin is based on the psychomotor skills development of children with celebral palsy, which are important for optimal preparation to being independent in the future, for attending school and to function in society.

Objective of taken actions is to change disfunction into ortofunction - to achieve an optimal level of child's development, that is possible to be realized according to his specific individual disorders and possibilities [3]. Thinking about children with nervous system damage the ortofunction may not be clearly termed by comparing their achievements with development achieved by others. Adaptation of the learning process to special needs and abilities of disabled children is based on few basic rules:

- Regularity rule - is to combine all interactions -educational, therapeutic and rehabilitation,

- the principle of individualization- adaptation the improvement process to individual needs and abilities of each child in the group,

- Corelation of functions rule- necessity of multiple profiling and mutual correlation in teaching all of functions,

- Practical action rule -tying theory and practice - transferring the achieved knowledge to conditions of live and application in practice,

- zasada poglądowości -learning by direct expe- rience, handling with right educational measures, apropriate equipment [7].

Proper implementation of the goals in our kindergarten is achieved through:

- the preparation of substantive

- organizational preparation - spacious rooms for classes, rehabilitation equipment, teaching equipment.

Creating the conditions for children activation in all areas requires adequate space (preschool room), adapted teaching aids and rehabilitation equipment.Learning self-movement of physically handicapped children is the basis for the implementation of self -service, cognitive and socialization tasks. With the delivery of the program, beside the typical rehabilitation equipment used by children (trolleys, scales, patient lifts, walkers, etc.) in Special Pre-school no 11 in Lublin we mainly use the equipment for developing hand skills.

- Educational - therapeutic work in group of children with cerebral palsy - organizational assumptions.

\section{Conditions for admission to kindergarten}

All children admited to the Special Pre-school no 11 in Lublin have opinion of need for special education based on the kind of possessed disability, issued by psycho - pedagogical counseling. This kind of document contains the diagnosis of child's disability and general guidelines according to organization of educational process according to the child. Those information are showing how the child is functioning, but because of the generality of it, this must be supplemented.

Creating an education and therapeutic system for the child in kindergarten starts with meeting parents and asking for information. In Special Pre-school we use an observation sheet made by our therapists.

Observation sheet contains information about child's functioning in individual spheres:

- self-service,

- cognitive,

- socio -emotional,

- communication,

- manual,

- physical.

Parents of the child are asked to complete the sheet, and then, after insightful observation of the child the therapists are supplementing the sheet. Construction of the document is clear, so that it allows to see the changes occurring in child's 
functioning during months of work. Therefore information taken from the observation sheet are the basic to create a functional diagnosis for every child by therapeutic team.

Information about physical sphere of the child are supplemented by using rating scale named GMFM (Gross Motor Function Measure). GMFM is based on neurophysiological basis of development and test on functional behavior of children in the field of large motor activity from infancy to 16 years of age. It allows to monitor even small progress in motor development of children, especially with spastic forms of the disease, which is often an important step in their individual functional capacity [2].

In the process of creating a functional diagnosis for each child all professionals working with the child are attended - a special education teacher, psychologist,speech therapist, physiotherapist .Each of them develops a program of activities in the sphere, that they are responsible for. These individual programs, based on in-depth diagnosis of a child, make up the Individual Education- Therapeutic Program(IPET), which is developed for each child, based on the specifics of its functioning and its individual needs and capabilities.

The document - functional diagnosis is developed during the school year. Then it is changed, preceded by conclusions taken during observation of the child ( $\mathrm{AO}$ and GMFM).Individual educational-therapeutic program includes a range of content from the core curriculum of preschool education, that the child will realize - this is a joint program of preschool education for all children in the group and individual guidance, as to the methods, forms and methods of implementation of the tasks for the child in all spheres of development.

The document "Functional Diagnosis" is discussed with parents to obtain their consent for the implementation of the program and to adopt rules of conducting in life outside the therapeutic preschool. Consistency effects of preschool and home is very important for achieving progress in the functioning of the child.

\section{The teaching - educational - therapeutic - educa- tional process}

Daily educational - therapeutic process proceeds in a specific day rhythm. Repeatability and structuring of individual activities allows to create a safe, friendly and predictable environment for children. Shaped this way, a sense of security in children increases their activity and the degree of autonomy in all their operations.

Day rhythm of children in kindergarten classes includes the following blocks:

- self- service block

I block- morning (around 8:30 - 9:30): breakfast, washing and wiping his face and hands, relieving physiological needs; II block -afternoon (around 12:00): training biting and swallowing food (dinner), washing and drying face and hands, relieving the physiological needs, preparing for a rest (dressing and undressing). During meals, beside special educator, children are accompained with: speach teacher (detailed implementing training of biting and chewing food with some children) and physiotherapist (consults children sitting position while eating). Children observation while performing the above steps allows the physiotherapist to not only determine which of these activities may be performed by a child, but it also allows to determinate the cause of dysfunction. Gathering these data is the basis to create a program by a physiotherapist for groups and individuals, mentioning the showed before, not yet fully mastered by the child elements of the movement. Their mastery allows the child to perform a certain functional action. The achievement of self -reliance by children with cerebral palsy in all basic activities is, next to school education master, kept as the main goal in our kindergarten improvement.

Matter of course for this, is putting the emphasis on improving motor development and functional of hands in conjunction with the development of gross motor skills. It should be noted that at the same time, the principles of prevention and perpetuating the abnormal patterns of alignment and movement are been taken care of. Simply made of tree equipment - chairs, ladders skid tables is helpful in implementation of the developed program. Their characteristic feature is the construction of rungs that enables "cylindrical"grip - with the opposition of the thumb. This structure allows a disabled child in any position (lying, sitting, standing and walking) to learn gripping, holding, release the grip, fixation, orientation in the midline and increases the feeling of safety while losing balance; makes it easier for the maintenance of posture and active change of position. The ability to stabilize the one hand, less efficient, assigns its important function - stabilization, which is important -mostly its instinctive functional elimination. 
This equipment enables efficient use of the hand, that is more efficient while decreasing the impact of spasticity [6]. Giving children opportunities to exercise tasks is essential to trigger the conscious motivation and active participation of children in the learning process.


- educational block in groups - takes place every day during $9.30-10.15$, and lasts about $30-40$ minutes. Educational content implemented then are common to all children (the program is centered), but the way of how to perform the task and the degree of teachers assistance is individualized for each participant; This kind of group activities is directed by special educator, and physical therapist - assists, facilitating the child to take proper alignment of the body and the development of proper movement patterns.
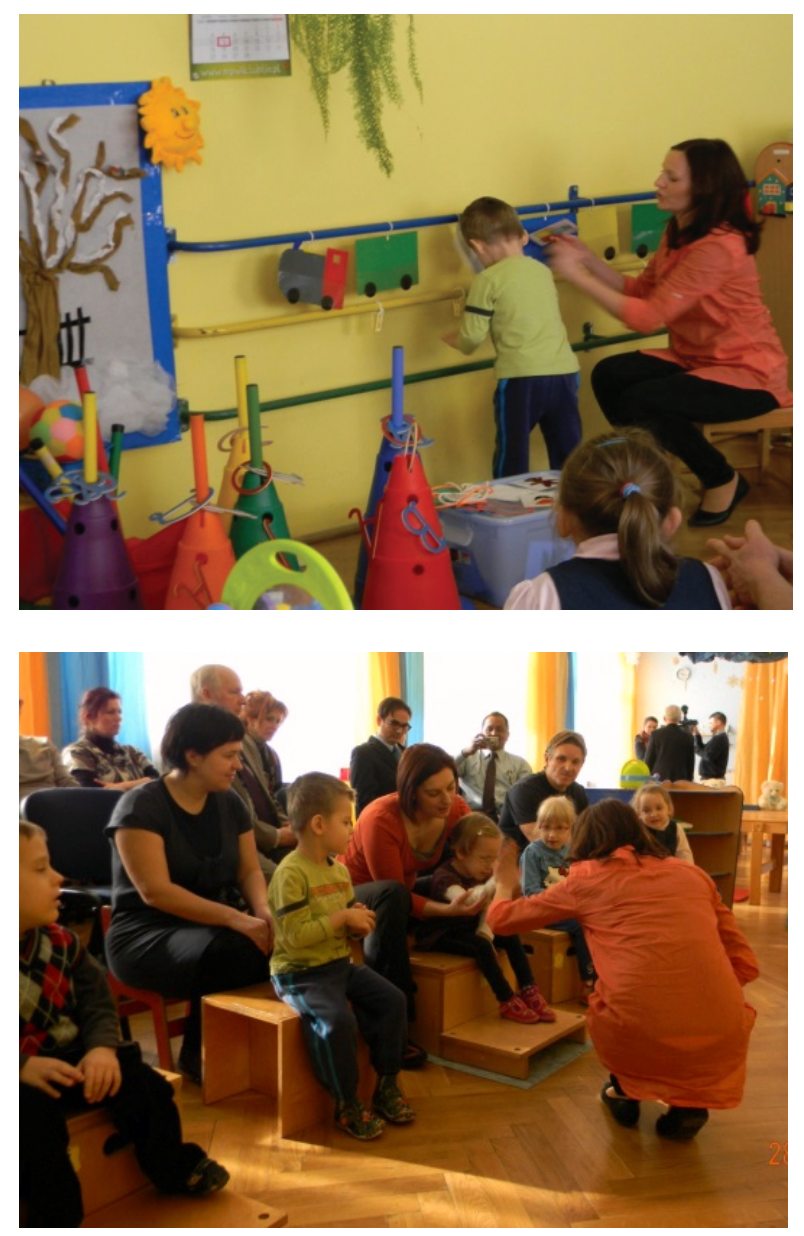

- rehabilitation block in groups (seated in chair or box "boxes") - are held daily, immediately after the end of educational blocks, last about 30 - 40 minutes; leading educator during these classes is a physiotherapist, planning their course schedule, sets out the objectives and planning how to achieve them. Special educator should reinforce desirable behaviors in children, and build a friendly and safe atmosphere conducive to the learning process; 

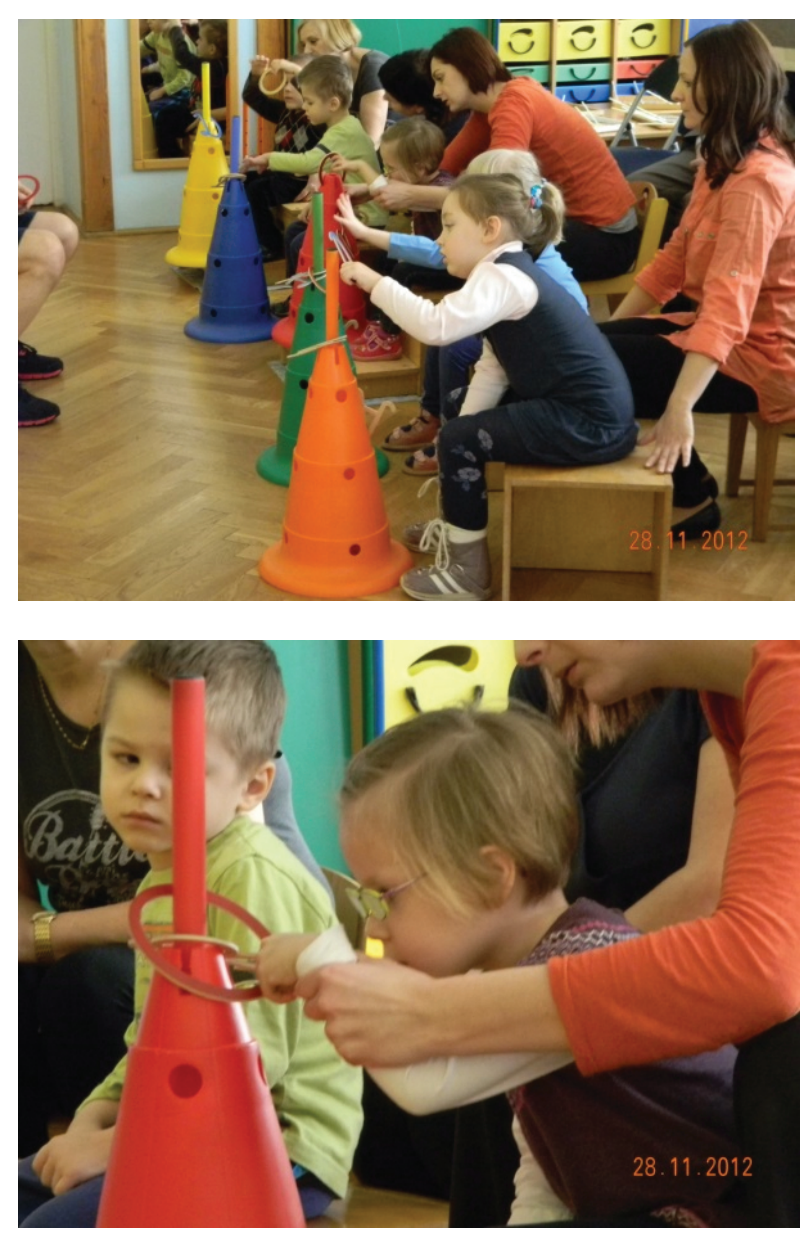

- individual educational classes block - takes place in the morning (to 8:30 am), and between hours. 14:00 and 15:00; is run by a teacher and a special education teacher and is to:

- denominate the child's cognitive processes for the maximum,

- offsetting existing constraints,

- optimal correction of disturbed functions,

- implement with individual child tasks that are closely related to the objectives set out in the Individual Educational-therapeutist Programmes (IPET);

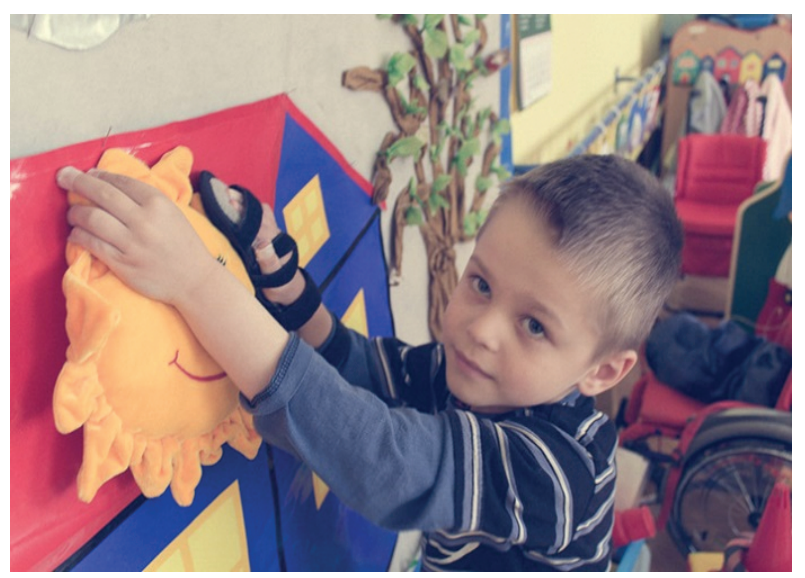

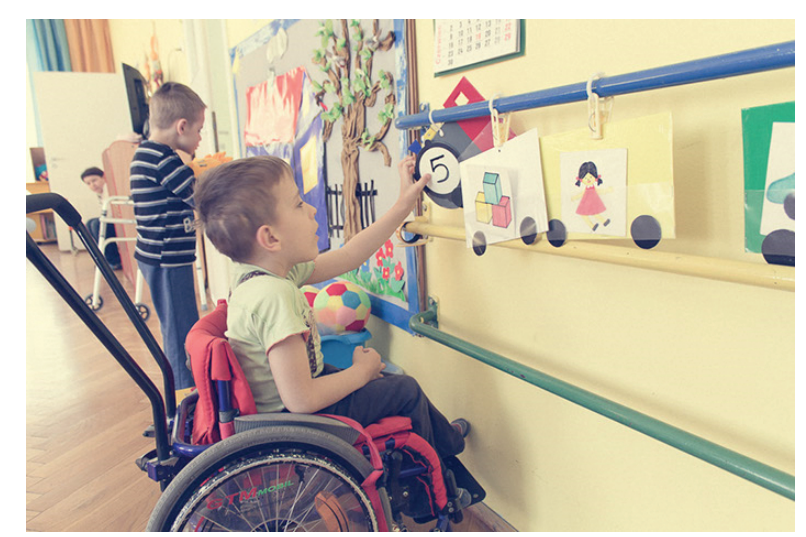

- individual rehabilitation classes block- classes are held in the morning - till breakfast and in the afternoon(after group classes block). Single sessions of movement for individual children last about 0.5 hours., are based on individual indications developed by a physiotherapist.
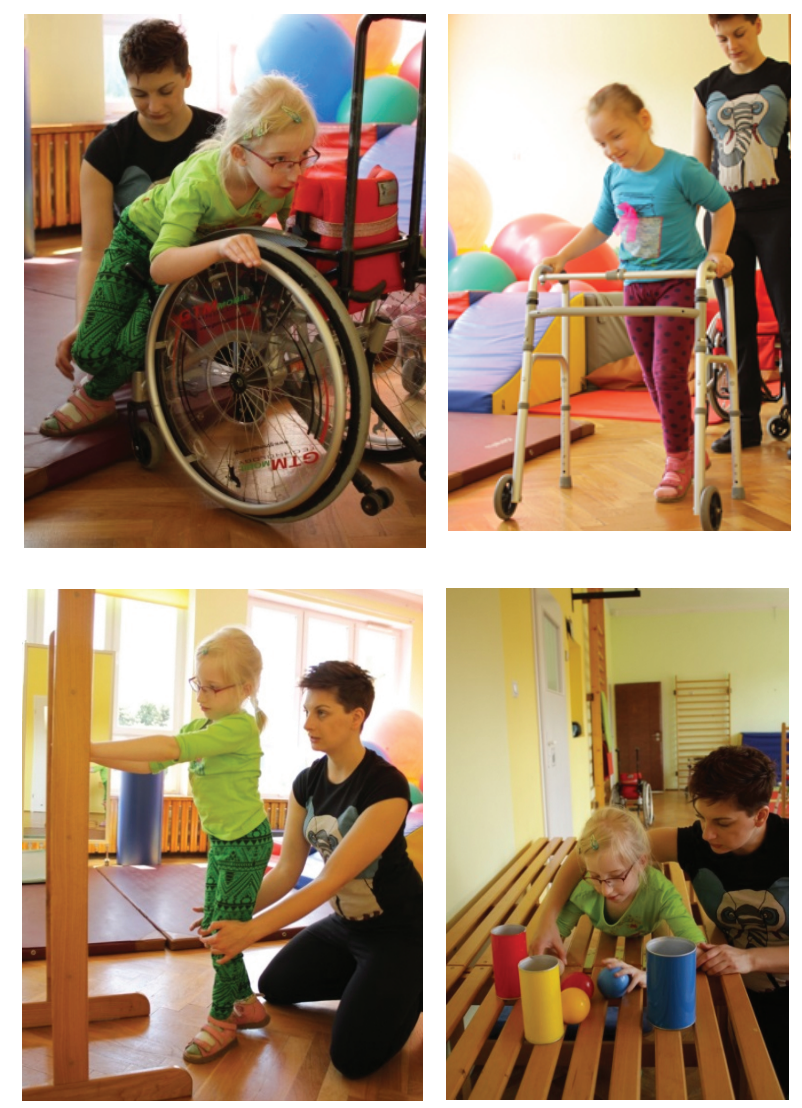

Other specialistic, individual classes are held at identical times, such as an individual rehabilitation activities; applicable classes: speech therapy, stimulating the development with psychologist, computer assisted rehabilitation, Multisensory stimulation, sensory integration.Detailed schedule and their range is developed individually for each child by a team of specialists. During its creation, we think about the individual needs of the child, 
its efficiency and the distribution of extra-curricular activities in which the child participates outside kindergarten.

Educational content implemented with children in the classroom have a "spiral pattern" - the range of material performed during group activities is gradually expanded and deepened, with the continuous retention of knowledge and skills in all types of activities carried out in the individual form.

Most important in the daily implementation of the educational- therapeutic process in our kindergarten is to organize the task situation so that it allows children to experience a sense of success, as far as their mental and physical capacity let them to, and thus shaping a sense of resourcefulness living.

\section{The team of therapists}

Team of specialists working with a group of children with physical disabilities is made of: special educators - 2 oligophrenopedagogst, 1 physiotherapist, 1 sensory integration therapist, one psychologist, one speech and language therapist; specialists in the field of - Multisensory stimulation and rehabilitation by working with computer ( 2 teachers). Additional staff in the group is to help preschool teacher, by assisting children during all activities led by teachers. During group activities, whose principal purpose is the development of cognitive skills tasks is guided by one person - a special education teacher, during the movement session the role of the teacher takes physiotherapist, and during the course of selfservice (meal) special educator is present and speech teacher or physical therapist, whose job is to individualize the scope given to children, to help. In addition to conduct, during all group activities, other persons are present as well (professionals, help to the teacher), whose role is to ensure the correct execution of the task by the child or children who are assisted by them.

The team of therapists working in the group organizes meetings of the Preschool Team Therapists (ZTP), which analyzes the level of operation for individual children, designate the directions of therapy (the development of functional diagnoses and IPET), the designation of joint and complementary areas of improvement for individual professionals working with the child, determine the dynamics of group work and the scope planned for implementation of educational content, evaluation of the realized therapeutic process. Team meetings are held as needed, not less than 3 times a year.

Position of preschool Team Therapists is discussed with parents on an individual meetings named TEAM, involving both parents and other important persons in child's environment ( grandparents) and all professionals working with the child. Due to the fact, that the family environment of the child is his original and natural, it is extremely important to transfer the rules of conducting with the child with physical disabilities in situations of everyday life, in order to stimulate them to maximize the development of self-reliance. So there is a great need to broaden the scope of our cooperation pursued with the family environment [5].

\section{References:}

1. Borkowska M, Derulska I, Eysymont- Barańska H. Dziecko z niepełnosprawnością ruchową. Jak wspomagać rozwój psychoruchowy. Warszawa: PZWL; 2012.

2. Klimont L. Zastosowanie skali funkcjonalnej GMFM (Gross Motor Function Measure) w terapii dzieci z Mózgowym Porażeniem Dziecięcym, materiały naukowe w: Coroczne spotkania terapeutów NDT- Bobath, IX Konferencja Naukowa, Warszawa, 2006.

3. Król M. System Nauczania Kierowanego. Zintegrowanie działań rehabilitacyjno- edukacyjno- społecznych wobec dzieci z wczesnym uszkodzeniem mózgu i ich rodzin, Stowarzyszenie Pomocy Dzieciom Niepełnosprawnym Krok za Krokiem, Zamość, 2007.

4. Levitt S. Rehabilitacja w porażeniu mózgowym i zaburzeniach ruchu, Warszawa: PZWL; 2007.

5. Mazanek E. Rola środowiska rodzinnego $\mathrm{w}$ usprawnianiu i wychowaniu dziecka

z mózgowym porażeniem, In: Dziecko niepełnosprawne ruchowo, cz. 3- wychowanie

i nauczanie. Warszawa: WSIP; 1998. 
6. Metera K. Usprawnianie dziecka z mózgowym porażeniem dziecięcym w systemie "dyrygowanego nauczania”, In: Łosiewski Z, Serejski J, editor. Mózgowe porażenie dziecięce. Aspekty medyczne, pedagogiczne i socjalne. Warszawa: OBR; 1985.

7. Wiśniewska M. Wspomaganie rozwoju dziecka z niepełnosprawnością intelektualną. Poradnik dla rodziców i terapeutów. Kraków: 2008.

\section{Correspondence address:}

Paulina Bartnik

Special Preschool no 11 in Lublin

Młodej Polski 30, 20 - 863 Lublin 